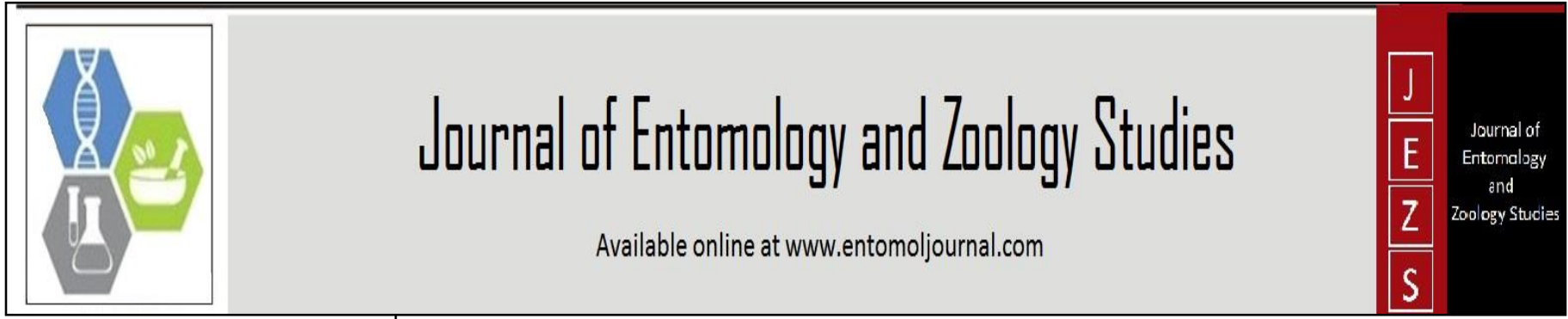

E-ISSN: 2320-7078

P-ISSN: 2349-6800

www.entomoljournal.com

JEZS 2021; 9(1): 105-109

(C) $2021 \mathrm{JEZS}$

Received: 15-11-2020

Accepted: 21-12-2020

Th. A Singha

Department of Sericulture,

Assam Agricultural University,

Jorhat, Assam, India

\section{P Rajkumari}

Department of Entomology,

Biswanath College of

Agriculture, AAU, Biswanath,

Assam, India
Corresponding Author:

P Rajkumari

Department of Entomology,

Biswanath College of

Agriculture, AAU, Biswanath, Assam, India

\section{Ovipositional behaviour of Callosobruchus chinensis $(\mathrm{L})$ in different pulses: A review}

\section{Th. A Singha and P Rajkumari}

DOI: https://doi.org/10.22271/j.ento.2021.v9.i1b.8801

\section{Abstract}

Pulse beetle, Callosobruchus chinensis is one of the major stored pests of pulses. There were various factors that influence the ovipositional behaviour of $C$. chinensis. The preference of host specificity for oviposition by the female pest is very important to lay maximum number of eggs and also for the survival of a species. Bigger size, smooth surface, deep coat and coloured seeds are the most suitable for oviposition. The combination of temperature and humidity also play important role in ovipositional behaviour of the pest. The numbers of egg deposition vary within the period of oviposition and the maximum eggs laid on the first day of oviposition decreases with the enhancement of period. Plant extracts may alter the ovipositional behaviour and could be one of best practical ability to control the destructive stored pest.

Keywords: Callosobruchus chinensis, pulse beetle, ovipositional behaviour and host preference

\section{Introduction}

Insects have been causing tremendous losses not only to the crops growing in fields but also to post-harvest commodities during storage. The pulse beetle, Callosobruchus species (Coleoptera: Bruchidae), is a major destructive pest of economically important leguminous grains such as cowpeas, lentils, green gram, and black gram, widely distributed around the world. (Talukder and Howse, 1994; Park, et. al. 2003; Srinivasan and Durairaj 2008) [57, 38, 53]. Insect oviposition is a complex but critical activity in the life cycle of an insect. Egg-laying behaviour is one of the most important aspects of female behaviour, and has a profound impact on the fitness of a species (Cury, et.al. 2019) ${ }^{[15]}$. Various factors that influence both physiology \& subsequent behaviour, that lead to egg deposition by an insect which tries to ensure safety to their progeny. Many females succeed but few may fail in their attempt to start new life. Pre-oviposition incorporates all the behaviours and factors involved in the selection of, or attraction to, an oviposition site and oviposition itself. The adult pulse beetle female lays eggs, which are glued to the seed surface. The larvae bore into the pulse grain, where the entire development takes place and the adults emerge out leaving behind holed grains. The grains, therefore, become unsuitable for human consumption, viability for replanting, or for the production of sprouts (Raja et. al. 2001) ${ }^{[40]}$.

\section{Ovipositional behaviour of Callosobruchus chinensis (L.)}

Ovipositional behaviour comprises one of the final steps in insect reproduction. It involves the deposition of the mature egg outside the body of the female and includes a series of behavioural and physiological events that begin with the movement of the egg through the oviduct and end with the placement of the egg on a substrate that will support the development of the larva. Specialized behaviours and structures on the female allow her to place the eggs within a protected environment during oviposition. Ovipositing females perceive cues on the host surface through a variety of sensory receptors such as gustatory, olfactory, and mechanical receptors located on different parts of the insect body such as antennae, tarsi, proboscis, labial palpi, and ovipositor (Stadler, 1974; Stadler, 1984; Ramaswamy, et. al. 1987 and Hansson, 1995) [55, 54, 42, 22]. In contact with various oviposition substrates, females of phytophagous insects perceived with their tactile and gustatory receptors the difference in the texture and chemical composition of the plant-host (Huignard, 1984 and Parr et. al. 1996) ${ }^{223,}$ 39]. 
Factors influencing ovipositional behaviour of $\boldsymbol{C}$. chinensis An understanding of the physiological, behavioural, ecological, or evolutionary interactions between these insects and their hosts requires precise representation of the events and factors influencing oviposition (Singer, 1986) ${ }^{[48]}$. Several investigations have shown that the progeny develops best on host chosen by their mother insect. Visual and mechanical properties can influence the oviposition behaviour, but chemicals of the environment seem in almost all insects to be of paramount importance. Since nutritional and allelochemical compounds determine successful development, it is not surprising that chemoreceptors plays crucial role during oviposition.

\section{Preference for egg deposition \\ Based on the pulse and cereal seeds}

Ovipositional preference and development of Callosobruchus chinensis (L.) (Coleoptera: Bruchidae) on five different leguminous seeds such as cowpea, white kidney bean, soybean, mung bean and azuki bean was studied both choice and no-choice tests revealed cowpea seed as the most preferred oviposition substrate (Mainali, 2015) ${ }^{[32]}$. Highest eggs deposition occurred on chickpea and the lowest eggs deposition was found in black gram among the pulse species. The egg deposition on mung bean and lentil were intermediate (Ahmed, et. al. 2018) ${ }^{[3]}$. The findings were in conformity with Singh, (1976) [51] who reported that $C$. chinensis preferred oviposition to chickpea followed by mung bean, lentil, black gram and bean in order of decreasing suitability. Bhaduria and Jakhmola (2006) ${ }^{[7]}$ reported that the ovipositional preference and survival of the pulse beetles on black gram which were less preferred for oviposition. Yunus et. al. (2015) ${ }^{[59]}$ observed significant differences among the oviposition rate on five different pulses (kidney beans, black gram, chickpea, Mung beans and cowpea and five different cereals (wheat, maize, pearl millet, barley and oat. The highest preference of oviposition was recorded on kidney beans $(147.67 \pm 0.58)$, mung beans $(132.00 \pm 2)$, whereas in the case of cereals on maize $(13.67 \pm 1.53)$ and wheat $(7.67 \pm 1.15)$.

\section{Based on the physical and morphological characters of seeds}

The variation of egg deposition on different pulse species associated with the physical and morphological characteristics of the seeds. The shape, colour and size of pulse seeds, curvature, texture and thickness of the seed-coat affected egglaying (Nwanze et. al. 1975). Ahmed, et al. (2018) [33, 3] revealed that he seeds of chickpea were large in size having larger surface area which favoured larger egg deposition. Bhattacharya and Banerjee (2012) ${ }^{[8]}$ found that eggs deposited on a garden pea seed were significantly greater than those deposited on a chickpea or a lentil seed. Chakraborty and Mondal (2016) [11] reported that pulse beetle laid maximum number of eggs in larger surface area of seed in kidney bean. This was in conformity with the observation of Teotia and Singh (1968) ${ }^{[58]}$ who found that the fecundity of C. chinensis depended upon the size and quality of seeds with seed coat. The fecundity of the weevil increased when smooth and well-filled seeds were provided for oviposition. In general, the bigger the size of the seed, the greater was the number of eggs laid per seed (Seddiqi, 1972). Lema (1994) ${ }^{[46,}$ 31] observed the variety with high rough and wrinkled and thick seed coat prove to be tolerant to choice for egg laying when compared with those having smooth, thin seed coat varieties could be the most preferred for egg laying. $C$. chinensis distributed eggs uniformly on grains of different 70 cowpea lines and oviposited a small number of eggs/grain having rough seed surfaces were less preferred. Brown, black, grey and red coloured seeds were more preferred than white coloured seeds. (Chavan, 1997) ${ }^{[13]}$.

\section{Based on the nutritional characters}

Chakraborty and Mondal (2016) ${ }^{[11]}$ investigated that relative preference of $C$. chinensis to different pulses varied widely depending upon their physical and chemical characteristics of seeds. Ovipositional preference was dependent on the seed color, seed texture, seed weight, thickness of seed coat, seed moisture and various chemical parameters. These findings were in accordance with the observation of Schoonhoven (1972) ${ }^{[45]}$ and found the variations in influence on the oviposition of the pulse beetle attributed to the odour emanating from the seed. The varieties with high protein content were most susceptible to pulse beetle ( $C$. chinensis $\mathrm{L}$.) than the varieties of low protein content. Ashfaque, et. al. (2001) ${ }^{[6]}$ also reported that the varieties with high protein content are highly preferred for oviposition by $C$. chinensis L. while varieties with low protein content are least preferred for oviposition (Kamble, et. al. 2016) ${ }^{[24]}$. Higher egg laying preference and shorter developmental time with longer adult longevity of the beetle on cowpea probably signifies importance of physical as well as chemical attributes of the seed as an oviposition substrate other than evolutionary history of the insect (Mainali, et. al. 2015) ${ }^{[32]}$.

\section{Period of oviposition}

Bhattacharrya and Banerjee (2012) ${ }^{[8]}$ assessed the factors affecting egg laying behavior and fecundity of $C$. chinensis $\mathrm{L}$ infesting stored pulses. They found that mated female deposited more eggs than the unmated ones. A female lay 50100 eggs on smooth legume pods (Smith 2015) ${ }^{[52]}$. The pre oviposition and oviposition period of $C$. cheninesis $\mathrm{L}$ was lasted for 4 to 14 hours and 6 to 8 days respectively. Pandey and Singh (1997) observed that maximum daily egg laying occurred in the first 24 hours, the number gradually dropped till the last day of oviposition. The fecundity of a single female of $C$. chinensis had been $30-110$ eggs at the rate of 1 - 35 per day. Prabha and Sehgal (1990) observed that aging has profound effects on fecundity and fertility of $C$. chinensis. Singh and Rina (2000) ${ }^{[49]}$ studied the biology of $C$. chinensis infesting the stored pulses like mung and lobia has proved that maximum egg output was observed on the first day of oviposition.

\section{Plant extracts on ovipositional behaviour}

Plant materials has an important role in insect pest control, including ash (Ofuya,1986 and Ajayi, et.al.1987) [34, 4], vegetable oils (Schoohoven, 1978 and Kazi, et. al. 1999) ${ }^{[44,}$ 25] plant extracts (Chiasson, et. al. 2004 and Devanand and Usha 2008) $[14,16]$ and botanical powders (Abdullahi and Muhammad 2004 and Gupta and Srivastava 2008) ${ }^{[1,21]}$. Kazi et.al. (2001) ${ }^{[26]}$ worked on effects of neem oil on mating and oviposition behaviour of azuki bean weevil, Callosobruchus chinensis and observed fecundity and emergence rate were always lower in oil-treated conditions. Similar findings were also reported by Khaire, et. al. (1993) and Pandey, et al. (1986). Singal and Chauhan (1997) ${ }^{[27,36,47]}$ tested the effect of neem seed oil and neem seed kernel powder individually prevented egglaying for up to 8 months of storage and a 
negligible adult population developed after this period. Subramanya, et. al. (1994) ${ }^{[56]}$ reported that the extracts of Eucalyptus citrodora gave a better reduction in the number of eggs oviposited and emerging adults. Rani, et. al. (2000) ${ }^{[43]}$ carried out a research using different vegetable oils such as cottonseed, neem, palm, rice, bean and soybean oils as surface protectants against C.chinensis on chickpea grains and reported the lowest fecundity. Singh (2003) ${ }^{[50]}$ checked the effect of some oils against C.chinensis infesting pigeonpea. Edible oils of coconut, mustard, sunflower, sesame and mahua and non-edible oils like neem, karanj, castor, tarpin and noorani as well as hair oil of arnica, himtaj, amla, banthol and navratan were used as surface protectants against C.chinensis at $8 \mathrm{ml} / \mathrm{Kg}$. seeds. All the oils proved highly effective in protecting the seed upto 9 months storage in terms of seed damage and weight loss. Rajak and Pandey (1964) ${ }^{[41]}$ reported the oils prevented egg laying and controlled the population buildup of the beetle. The oils of taramira, coconut, sunflower, safflower and castor were found more effective in reducing the egg laying at $1 \mathrm{ml}$ and 3 Page 16 $\mathrm{ml} / \mathrm{Kg}$. seed as compared to other oils. Bushra and Devi 2020 ${ }^{[10]}$ studied on effect of edible oils on different stages of pulse beetle (Callosobruchus chinensis L.) on chickpea grains. Among the five edible oils viz. olive oil (Olea europaea L), coconut oil (Cocos nucifera L.), groundnut oil (Arachis hypogaea L.), mustard oil (Brassica spp L.) and sesame oil (Sesamum indicum L.), coconut oil at $9 \mathrm{ml} \mathrm{kg}^{-1}$ grains was found to be most effective in inhibiting the oviposition $(26.43$ eggs). Akter, et.al. (2019) ${ }^{[5]}$ informed soybean oil was the best to decrease the rate of oviposition than the black seed oil and sesame oil.

\section{Effect of temperature on ovipositional behaviour}

Temperature plays a major role in growth and development of insects. The optimal temperature for egg laying and development of stored product insects was between $25^{\circ} \mathrm{C}$ and $35{ }^{\circ} \mathrm{C}$ while temperature between $13{ }^{\circ} \mathrm{C}$ and $25{ }^{\circ} \mathrm{C}$ made the development of insects (metabolic activity) slower. Most of the stored product insects stopped their development at $20^{\circ} \mathrm{C}$ (Ghosh and Durbey 2003). Khalil and Ali 1999, Bursell, 1974; Kim and Choi, 1987, Graeme and Zalucki, 1991, and Ahmad, et. al. 1993) [19, 28, 9, 29, 20, 2] observed that fecundity and longevity were found to be significantly less at higher temp. Flinn and Hagstrum (1990) and Evans, 1983) [18, 17] revealed that fecundity was reduced and development of insect was slow at low temperature between $20^{\circ} \mathrm{C}$ to $10^{\circ} \mathrm{C}$. Temperature selection might be affected by humidity or state of hydration of the insects (Chapman, 1965) ${ }^{[12]}$, they might together affect fecundity and longevity markedly Lale and Vidal (2003) ${ }^{[30]}$ evaluated four temperatures $\left(25^{\circ} \mathrm{C}, 30{ }^{\circ} \mathrm{C}\right.$, $35^{\circ} \mathrm{C}$ and $40{ }^{\circ} \mathrm{C}$ ) and three humid levels $(30 \%, 60 \%$ and $90 \%$ R.H) for their effect on oviposition and development of stored beetles in pure and mixed populations on groundnut, where temperature influenced oviposition significantly more than humidity. Omar and Mahmoud (2020) ${ }^{[35]}$ found egg-laying was optimal at temperature range of $30-35{ }^{\circ} \mathrm{C}$. The study showed the temperature had significant effect on the preoviposition, oviposition and post-oviposition periods.

\section{Conclusion}

The pulse beetle, Collosobruchus chinensis L. has a great tendency to deposit maximum number of eggs in the seeds having larger surface area, smooth and deep coat. The number of laid eggs varied according to the surface area and chemical composition of seed where they feed and also has significant influencing the egg deposition and damage of seed. The plant extracts are safe, cheap, residue free and eco- friendly materials that can inhibit the egg deposition and fit into the IPM package of stored grain pests. The current research paves the way to provide awareness to the farmers not to store seeds in the same place or at the same time to avoid cross infestation because of their high susceptibility to $C$. chinensis.

\section{References}

1. Abdullahi YM, Muhammad S. Assessment of the toxic potentials of some plants powders on survival and development of Callosobruchus maculatus. African Journal of Biotechnology 2004;3:60-62.

2. Ahmed M, Borsch CM, Neyfakh AA, Schuldiner S. Mutants of the Bacillus subtilis multidrug transporter Bmr with altered sensitivity to the antihypertensive alkaloid reserpine. J Biol Chem 1993;268(15):110861108

3. Ahmed, Salim, Haque, Azizul MD, Mahmud Hyat. Effect of Pulse Beetle, Callosobruchus chinensis $\mathrm{L}$ on Oviposition and Damage In Some Important Genotypes of Pulse Crops In Bangladesh. Biomed J Sci \& Tech Res 2018;2(2):1544-1548

4. Ajayi O, Arokoyo J, Nesan OO, Olaniyan M, NdireMbula M. Laboratory assessment of the efficacy of some local materials for the control of storage insect pests. Samaru J Agric Res 1987;5:81-85.

5. Akter Sharmin, Sultana Shanjida, Akter Tangin, Begum Shefali. Oviposition deterrent and ovicidal activity of three edible oils (black seed, sesame and soybean oils) against pulse beetle, Callosobruchus chinensis (Lin.) (coleoptera: bruchidae) on green gram, Vigna radiate. Bangladesh J. Zool 2019;47(1):59-65

6. Ashfaque M, Khalil SK, Zeb A. Oviposition and development of Pulse beetle (Callosobruchus maculates) on seed of chickpea varieties. M.Sc. (Hons.) thesis, Department of Plant Protection, NWFP Agriculture University, Peshawar, Pakistan 2001,135p.

7. Bhaduria NS, Jakhmola SS. Effect of intensity of infestation caused by pulse beetle on extent of losses and seed germination in different pulses. Indian Journal of Entomolgy 2006;68:92-94.

8. Bhattacharya B, Banerjee TC. Factors affecting egglaying behavior and fecundity of Callosobruchus chinensis (L.) (Coleoptera: Bruchidae) infesting stored pulses. Oriental Insects 2012;35(1):373-386

9. Burshell E. Environmental aspects- temperature. In: the physiology of insect (ed. M. Rockstein), Academia Press, New York, London 1974;II:5-16.

10. Bushra SN, Devi TB. Effect of edible oils on different stages of pulse beetle (Callosobruchus chinensis L.) on chickpea grains. Journal of Agriculture and Ecology, [S. 1.] 2020;9:41-47

11. Chakraborty S, Mondal P. Physico-chemical parameters of pulses affecting the bruchid (Callosobruchus chinensis Linn) Infestation. Asian Journal of Science and Technology 2016;7(3):2554-2560.

12. Chapman RF. The behaviour of nymphs of Schistocera gregaria (Forskal) in a temperature gradient, with special reference to temperature preference. Behaviour 1965;24:285-317

13. Chavan PD, Yeshbir Singh, Singh SP. Ovipositional preference of Callosobruchus chinensis for cowpea lines. 
Indian Journal of Entomology 1997;59(3):295-303

14. Chiasson $\mathrm{H}$, Vincent $\mathrm{C}$, Bostanian NJ. Insecticidal properties of a Chenopodium-based botanical. J Econ Entomo 2004;97:1378-1383.

15. Cury, Kevin M, Prud'homme, Benjamin, Gompel Nicolas. A short guide to insect oviposition: when, where and how to lay an egg. Journal of Neurogenetics 2019,33(2)

16. Devanand P, Usha, Rani P. Biological potency of certain plant extracts in management of two lepidopteran pests of Ricinus communis L. Journal of Biopesticides 2008;1:170-176.

17. Evans DE. The influence of relative humidity and thermal acclimation on the survival of adult grain beetles in cooled grain. J. Stored Prod. Res 1983;19:173-180

18. Flinn PW, Hagstrum DW. Simultaneous comparing the effectiveness of various stored grain management practices and to control Rhizopertha dominica. Environ. Entomol 1990;19:725-729.

19. Ghosh SK, Durbey SL. Integrated management of stored grain pests. International Book Distributing Co., Lucknow, India 2003.

20. Graeme HJ, Zalucki MP. Effect on temperature on development ration, survival and fecundity of cotton tip worm. Aust. J. Zool 1991;39(2):191-200

21. Gupta L, Srivastava M. Effect of Withania somnifera extracts on the mortality of Callosobruchus chinensis L. Journal of Biopesticides 2008;1:190-192

22. Hansson BS. Olfaction in Lepidoptera. Experientia 1995;51: 1001-1027

23. Huignard J. Approche écophysiologique de la reproduction chez les insects. Bulletin de la Société Entomologique de France 1984;89:924-931

24. Kamble SM, Bagde AS, Patil RR. Oviposition Preference of Pulse Beetle on Different Cultivars of Chickpea. Journal of Global Sciences 2016;5(6):4197- 4201

25. Kazi SA, Takao I, Toshihide I. Effects of plant oils on oviposition preference and larval survivorship Callosobruchus chinensis (Coleoptera: Bruchidae) on azuki bean. J App Entomol and Zoology 1999;34:547550.

26. Kazi SA, Yukio Y, Toshihide I. Effects of Neem Oil on Mating and Oviposition Behaviour of Azuki Bean Weevil, Callosobruchus chinensis L. (Coleoptera: Bruchidae). Pakistan Journal of Biological Sciences 2001;4:1371-1373.

27. Khaire VM, Kachare BV, Mote UN. Effect of different vegetable oils on ovipositional preference and egg hatching of Callosobruchus chinensis Linn. on pigeonpea seeds. Department of Entomology, Mahatma Phule Agricultural University, Seed Research Journal 1993;21:128-130

28. Khalil Y, Ali F. Effect of temperature on Callosobruchus chinensis (Bruchidae: Coleoptera) reared on different stored products. Pakistan Journal of Zoology 1999;14:516

29. Kim KC, Choi HS. Effects of temperature on the oviposition, feeding and emergence of the azuki bean weevil (Callosobruchus chinensis L.) in the stored beans. Kor J Plant Prot 1987;26:71-81

30. Lale NES, Vidal S. Effect of constant temperature and humidity on oviposition and development of Callosobruchus maculatus (F) and Callosobruchus subinnotatus (Pic.) on bambara groundnut, Vigna subterranea (L.) Verdcourt. Journal of Stored Products Research 2003;39:459-470.

31. Lema T. Screening of Chickpea Genotypes Agains Adzuki Bean Beetle (Callosobruchus chinensis, L.). Proceedings of the First Annual Conference Crop Protection Society of Ethiopia. Eshetu Bekele; Yitbarek Semeane; Tibebu Habtewold; Mengistu Kebede; Kasahun Bekele. Addis Abeba (Ethiopia). CPSE 1994.

32. Mainali BP, Kim, Hyun Ju, Park, Chung Gyoo, Kim et al. Oviposition preference and development of azuki bean weevil, Callosobruchus chinensis, on five different leguminous seeds. Journal of Stored Products Research 2015;61:97-101

33. Nwanze KF, Horber E, Pitts CWP. Evidence of ovipositional preference of Callosobruchus maculatus for cowpea varieties. Environmental Entomology 1975;4:409-412

34. Ofuya TT. Use of wood ash, dry chilli, pepper fruits and onion scale leaves for reducing $C$. Maculates damage in cowpea seeds during storage. Journal of Agricultural Science 1986;107:467-468.

35. Omar YM, Mahmoud M. Effects of three constant temperature ranges to control Callosobruchus chinensis (Coleoptera: Bruchidae): a serious pest of pulses in Egypt. Int J Trop Insect Sci 2020.

36. Pandey ND, Mathur KK, Pandey S, Tripathi RA. Effect of some plant extracts against pulse beetle, Callosobruchus chinensis Linnaeus. Indian Journal of Entomology 1986;48:85-90.

37. Pandey NK, Singh SC. Observations on the biology of the pulse beetle Callosobruchus chinensis (L.) infested stored pulses. Uttar Pradesh Journal of Zoology 1997;17(1):38-42.

38. Park C, Kim SI, Ahn YJ. Insecticidal activity of asarones identified in Acorus gramineus rhizome against three Coleopteran stored - product insects. Journal of Stored Product Research 2003;39:332-342.

39. Parr MJ, Tran BMD, Simmonds MSJ, Credland PF. Oviposition behaviour of the cowpea seed beetle, Callosobruchus maculatus. Physiological Entomology 1996;21:107-117.

40. Raja N, Albert S, Ignacimuthu S, Dorn S. Effect of plant volatile oils in protecting stored cowpea Vigna unguiculata (L.) walpers against Callosobruchus maculatus (F.) (Coleoptera: Bruchidae) infestation. Journal of Stored Products Research 2001;37(2):127132.

41. Rajak RL, Pandey ND. A life history study of the pulses beetle Callosobruchus chinensis (L) (Coleoptera: Bruchidae). Labdev. J. Sci. Tech 1965;3:119-123.

42. Ramaswamy SB, Ma WK, Baker GT. Sensory cues and receptors for oviposition by Heliothis virescens. Entomol. Exp. Appl 1987;43:159-168.

43. Rani CS, Vijayalakshmi K, Rao PA. Vegetable oils as surface protectants against bruchid, Callosobruchus chinensis (Linn.) infestation on chickpea. Indian Journal Plant Protection 2000;28(2):184-186.

44. Schoohoven AV. Use of vegetable oils to protect stored beans from Bruchid attack. J Econ Entomol 1978;1:254256.

45. Schoonhoven LM. Secondary plant substances and insects. In Structural and Functional Aspects of Phytochemistry and edited by Runeckles VC, Tso TC 1972;5:197-224. 
46. Seddiqi PM. Studies on Longevity, Oviposition, Fecundity and Development of Callosobruchus chinensis L. (Coleoptera; Bruchidae). Journal of Applied Entomology 1972;72:1-4,66-72

47. Singal SK, Chauhan R. Effect of some plant products and other materials on development of pulse beetle, $C$. chinensis (L.) on stored pigeonpea Cajanus cajan (L.) Millspp. J. Insect Sci 1997;10(2):196-197.

48. Singer MC. The Definition and Measurement of Oviposition Preference in Plant-Feeding Insects. In: Miller J.R., Miller T.A. (eds) Insect-Plant Interactions. Springer Series in Experimental Entomology. Springer, New York, NY 1986.

49. Singh AC, Rina Kumari. A study of the biology of Callosobruchus chinensis (Linn.) infesting stored pulses (Grain Legumes) in India. Indian Journal of Entomology 2000;42(4):319-320.

50. Singh PK. Effect of some oils against pulse beetle, Callosobruchus chinensis (Linn.) infesting pigeonpea. Indian Journal of Entomology 2003;65:55-58.

51. Singh Y. Studies on relative resistance of important pulses to Callosobruchus maculatus (Fabricius) and Callosobruchus chinensis (Linnaeus). Entomologists Newsleter 1976;6(2):18-19.

52. Smith HM. Callosobruchus chinensis. Plant pest of the middle east. Powered by Hugo by Steve Francia, style based on spf 132015.

53. Srinivasan T, Durairaj C. "Damage Potential of Bruchids in Different Edible Legumes and Interspecific Competition Between Two Species of Callosobruchus spp. (Bruchidae: Coleoptera)". ICFAI Journal of Life Sciences 2008;2(4):42-49. Archived from the original on 2015-09-07. Retrieved 2014-11-28.

54. Stadler E. Contact chemoreception. In W. J. Bell and R. T. Carde' [eds.], Chemical ecology of insects. Sinauer, Inc., Sunderland, MA 1984,3-35p.

55. Stadler E. Host plant stimuli affecting oviposition behavior of the eastern spruce budworm. Entomol. Exp. Appl 1974; 17:176-188.

56. Subramanya S, Babu CK, Krishnappa C, Krishna Murthy $\mathrm{KC}$. Use of locally available plant products against Callosobruchus chinensis in redgram. Mysore Journal of Agricultural Sciences 1994;28:328-334.

57. Talukder FA, Howse PE. Repellent, toxic, and food protectant effects of pithraj, Aphanamixis polystachya extracts against pulse beetle Callosobruchus chinensis in storage. Journal of Chemical Ecology 1994;20:899-908.

58. Teotia TPS, Singh VS. The effect of host species on the oviposition, fecundity and development of Callosobruchus chinensis L (Bruchidae: Coleoptera). Rev Appi Ent 1968;56(3):171.

59. Yunus FN, Asif K, Rashid F. Oviposition behavior of pulse beetle Callosobruchus chinensis (L) reared on different pulses and cereals. Biomed Lett 2015;1(1):5-8. 